\title{
EXPLORATION OF ANTI-CANCEROUS MEDICINAL PLANTS OF NASIK DISTRICT, MAHARASHTRA, INDIA.
}

\author{
D. G. Shimpi and M. V. Gavali \\ RNC \& Arts, JDB Commerce, \& NSC Science College, Nasik Road, Maharashtra, India, 422101 \\ Corresponding E.mail:- manishagavali83@gmail.com
}

\begin{abstract}
:
The present study was undertaken in the remote area of Nasik District of Maharashtra, India for exploration of anti-cancerous plants. Near about 32 plant species were studied which are used for cancer treatment Due to change in life style and hazardous pesticides are used for increase in the yield of crop, peoples are suffering from malignant growth of Cancer cells. Globally cancer is a disease which severely effects the human population. There is a constant demand for new therapies to treat and prevent of this life-threatening disease. Various plants like Acorous, Andrographis, Curcuma can be used for the treatment of cancer since of human history and on the basis of modern medicine. The use of leaves, tubers rhizomes, bulbils, fruits, Seeds, flowers etc. are used to cure cancer treatment. anti-cancerous molecules are identified \& isolated from plants for treatment. The tribal are used extract of various plant part for anti-cancerous activity. The plants can produces naturally occurring secondary metabolites which are being investigated for their anti-cancerous activities leading to the development of new clinical drugs.
\end{abstract}

Key word: - Nasik District, Cancer, Anticancerous plants, Tribal.

\section{INTRODUCTION:}

Nashik district is located in the North west side of the Maharashtra state It lies between latitude $19^{\circ}, 35^{\prime} \& 20^{\circ} 50^{\prime}$ and longitude $73^{\circ}, 30^{\prime} \&$ $74^{\circ}, 55^{\prime}$. It situated on the Westerns Ghats of Sahyadri ranges. Evergreen and dry deciduous type forest present in study area.

The plants are an important source of various crude drugs; these plants are used by tribal peoples in their day today due to their enormous potential. Plants have been used in medicine for their natural antiseptic properties. Many plants species are being used for treatment or to prevent cancer.

From the period of Rugveda, Athraveda, Samveda, Yajurveda herbal medicines have been used $\&$ are still used in developing countries as the primary source of medical treatment.

The remote area peoples have tremendous knowledge about medicinal properties \& uses of plants. the modern medicinal therapy is costly as compare to traditional folk medicine, it is safe and easily available for them.

\section{MATERIALS \& METHODS:}

The ethnomedicinal surveys was carried out in the remote area of Nasik district like peth, Hursul, Igatpuri, Surgana with the help of tribal, near about 2-3 years in all seasons. Plants specimens were collected, identified with the help of floras (T. Cooke1958, Lakshminarsimhan \& Sharma 1991) preserved in the form of herbarium. Information about traditional medicines were collected from the tribal peoples for cancer treatment suchas local name, plant part used, doses etc.

Geography and Climate:

Temp. $-5.5^{\circ} \mathrm{C}-25^{\circ} \mathrm{C}$ in winter season. $24^{\circ} \mathrm{C}-46^{\circ} \mathrm{C}$ in summer season.

Humidity - 90-95 \% in Monsoon season.

$20-25 \%$ in summer season.

\section{RESULT AND DISCUSSION:}

The remote pockets of Nasik district have a wide range of different plants. About 32 indigenous medicinal plants belonging to 24 families have been documented for cancer treatment as shown 
in table. The data analyses that the tribal peoples of remote area of Nasik district are used leaves, flowers, fruits, roots, rhizome as an anticancerous plant to cure cancer.

The local vaidya's are used herbal extract. The tribal peoples undergo such type of folk medicine. It was traditional knowledge about plants that were used to cure cancer and various diseases.

\section{CONCLUSION:}

Cancer is the most common disease; the allopathic treatment can cause adverse effect which is costly thus herbal medicines are used to cure cancer and to maintain and stop the malignant growth of cancer cells. The above study conclude that the traditional medicine is a set of practices handed over from one generation to another generation. The survey indicated that the study area has many of medicinal plants to treat various ailments.

The thorough investigation may use for various pharmaceutical industries for preparation of proper medicine cancer treatment.

\section{REFERENCES}

Cooke T, flora of the Presidency of Bombay Vol. I-III, BSI Calcutta, Reprint Edn, 1958.

Liu Z, Ma L \& Zhou G.B. The main anticancer bullets of the Chinese medicinal herb, tunder god vine. Molecules 2011; 16(6):5283-97.

M.V. Patil and D.A. Patil, folk medicine of Nasik district Jan.2001. Ancient Science of life. Vol. No. XX. 26-30

P. Lakshminarsimhan \& B.D. Sharma 1991, flora of Nasik district, Botanical survey of India Calcutta.

Sharma B.D.\& P. Lakshminarsimhan 1986. Ethanobotanical studies on tribal of Nasik district, J. Econ. Tax. Bot. 8:439454.

Subrata De And Suparna De June 2012 Gymnosporia Montana, A potential Hepatoprotective and Anticancer Drug An overview. Asian Journal of Pharmaceutical \& Clinical Research. Vol. 5. 20-24.

\begin{tabular}{|c|c|c|c|c|c|}
\hline $\begin{array}{l}\text { Sr. } \\
\text { no. }\end{array}$ & Name of the plant & Family & Local name & Parts use & Doses \\
\hline 1. & Acorus calamus Linn. & Acoraceae & Vekhand & $\begin{array}{l}\text { Root \& } \\
\text { Rhizomes }\end{array}$ & $\begin{array}{l}\text { Root and Rhizomes } \\
\text { extract is given twice in } \\
\text { day }\end{array}$ \\
\hline 2 & Aegle marmelos Linn. & Rutaceae & Bel & Leaves & Leaves extract is given \\
\hline 3 & Aloe vera (․․) Burm.f. & Asphodelaceae & Korphad & Leaves & Gel of leaf extract \\
\hline 4 & $\begin{array}{l}\text { Alpini agalanga (L.) } \\
\underline{\text { Willd. }}\end{array}$ & Zingiberaceae & Blue ginger & Rhizome & $\begin{array}{l}\text { one cup Extract of } \\
\text { rhizomes in early in the } \\
\text { morning }\end{array}$ \\
\hline 5 & $\begin{array}{l}\text { Amooar arohituka } \\
\text { Roxb. }\end{array}$ & Meliaceae & Rohitak & Stem, bark & $\begin{array}{l}\text { Extract of stem bark in } \\
\text { early in the morning }\end{array}$ \\
\hline 6 & $\begin{array}{l}\text { Androgrphis } \\
\text { paniculata (Burm.f.) } \\
\text { Nees }\end{array}$ & Acanthaceae & $\begin{array}{l}\text { Green } \\
\text { Chirayata }\end{array}$ & Leaves & $\begin{array}{l}\text { Extract of leaves is given } \\
\text { early in the morning }\end{array}$ \\
\hline 7 & $\begin{array}{l}\text { Asparqagus } \\
\text { racemosus Willd. }\end{array}$ & Asperagaceae & Shatavari & Rhizomes & Extract of rhizomes \\
\hline 8 & $\begin{array}{l}\text { Azadirachta indica } \underline{A} . \\
\text { Juss. }\end{array}$ & Meliaceae & Neem & Leaves & $\begin{array}{l}\text { One cup of leaf extract is } \\
\text { given early in morning }\end{array}$ \\
\hline 9 & $\begin{array}{l}\text { Bauhinia varieghata } \\
\text { (L.) Benth. }\end{array}$ & Fabaceae & Kanchan & Leaves & $\begin{array}{l}\text { Leaf extract are early in } \\
\text { the morning }\end{array}$ \\
\hline 10 & $\begin{array}{l}\text { Bryophyllum } \\
\text { pinnatum(Lam.) Oken }\end{array}$ & Crassulaceae & Pan-phuti & Leaves & $\begin{array}{l}\text { one cup leaves extract } \\
\text { early in the morning }\end{array}$ \\
\hline
\end{tabular}




\begin{tabular}{|c|c|c|c|c|c|}
\hline 11 & $\begin{array}{l}\text { Catharaqnthus } \\
\text { roseus (L.) G.Don }\end{array}$ & Apocynaceae & Sadhaphuli & Leaves & $\begin{array}{l}\text { Leaf extract is given } \\
\text { twice in a day }\end{array}$ \\
\hline 12 & Curcuma longa Linn. & Zingiberaceae & Turmeric & Rhizome & $\begin{array}{l}\text { one cup Extract of } \\
\text { rhizome early in the } \\
\text { morning }\end{array}$ \\
\hline 13 & $\begin{array}{l}\text { Emblica officinalis } \\
\text { Linn. }\end{array}$ & Phyllantheceae & Amla & Fruit & $\begin{array}{l}\text { one cup Fruit juice early } \\
\text { in the morning }\end{array}$ \\
\hline 14 & Glycine $\max (\underline{L}$.$) Merr.$ & Fabaceae & Soyabeen & Seed & Boiled seed extract is use \\
\hline 15 & $\begin{array}{l}\text { Glycyrrhiza glabra } \\
\text { Linn. }\end{array}$ & Fabaceae & Jeshthamadh & Rhizome & $\begin{array}{l}\text { Extract is given twice in } \\
\text { a day }\end{array}$ \\
\hline 16 & $\begin{array}{l}\text { Gossypium hirsutum } \\
\text { Linn. }\end{array}$ & Malvaceae & Cotton & Seed & $\begin{array}{l}\text { seed extract are used } \\
\text { twice in a day }\end{array}$ \\
\hline 17 & $\begin{array}{l}\text { Gymnosporia } \\
\text { Montana Roth. } \\
\text { Benth. }\end{array}$ & Celastraceae & Henkal & $\begin{array}{l}\text { Whole plant } \\
\text { \& Leaves }\end{array}$ & $\begin{array}{l}\text { Extract of leaves, stem, } \\
\text { root given early in the } \\
\text { morning }\end{array}$ \\
\hline 18 & $\begin{array}{l}\text { Morinda citrifolia } \\
\text { Linn. }\end{array}$ & Rubiaceae & Bartondi & Leaves & $\begin{array}{l}\text { One cup of leaf Extract } \\
\text { given early in the } \\
\text { morning }\end{array}$ \\
\hline 19 & Nigella sativa Linn. & Ranunculaceae & Kalonji & Seed & $\begin{array}{l}\text { Powder of seed is given } \\
\text { with warm water }\end{array}$ \\
\hline 20 & $\begin{array}{l}\text { Ocimum sanctum } \\
\text { Linn. }\end{array}$ & Lamiaceae & Tulsi & $\begin{array}{l}\text { Leaves, } \\
\text { stem, root }\end{array}$ & $\begin{array}{l}\text { Extract one cup early in } \\
\text { the morning }\end{array}$ \\
\hline 21 & $\begin{array}{l}\text { Oldenlandia diffusa } \\
\text { Linn. }\end{array}$ & Rubiaceae & $\begin{array}{l}\text { Snake needle } \\
\text { grass }\end{array}$ & Leaves & $\begin{array}{l}\text { One tablespoon extract } \\
\text { of leaves given early in } \\
\text { the morning }\end{array}$ \\
\hline 22 & Piper longum Linn. & Piperaceae & Pimpli & Fruit, leaf & $\begin{array}{l}\text { One cup extract early in } \\
\text { the morning }\end{array}$ \\
\hline 23 & $\begin{array}{l}\text { Psoralea corylifolia } \\
\text { Linn. }\end{array}$ & Fabaceae & Bawchi & Seed, fruit & $\begin{array}{l}\text { One teaspoon Dried } \\
\text { powderalonf with warm } \\
\text { water given early in the } \\
\text { morning }\end{array}$ \\
\hline 24 & cordifolia & Rubiaceae & Manjistha & Root & $\begin{array}{l}\text { one cup Boiled extract of } \\
\text { root given before tea }\end{array}$ \\
\hline 25 & $\begin{array}{l}\text { Saussure alappa } \\
\text { Linn }\end{array}$ & Asteraceae & Kustha & Root & $\begin{array}{l}\text { one cup Boiled extract of } \\
\text { root given before tea }\end{array}$ \\
\hline 26 & $\begin{array}{l}\text { Solanum nigrum } \\
\text { Linn. }\end{array}$ & Solanaceae & Kamchi & Leaves & $\begin{array}{l}\text { one cup Boiled extract of } \\
\text { leaf given before tea }\end{array}$ \\
\hline 27 & $\begin{array}{l}\text { Solanum surattense } \\
\text { Linn. }\end{array}$ & Solancaceae & kateringani & Fruit & $\begin{array}{l}\text { one teaspoon Extract of } \\
\text { fruit early in the morning }\end{array}$ \\
\hline 28 & $\begin{array}{l}\text { Terminalia chenbula } \\
\text { Retz. }\end{array}$ & Combretaceae & Hirda & $\begin{array}{l}\text { Seed, fruit, } \\
\text { leaf }\end{array}$ & $\begin{array}{l}\text { One teaspoon of Seed } \\
\text { power or extract given } \\
\text { before tea }\end{array}$ \\
\hline 29 & $\begin{array}{l}\text { Tinospora cordifolia } \\
\text { (Thunb.) Miers }\end{array}$ & Menispermiaceae & Gulvel & $\begin{array}{l}\text { Leaves } \quad \& \\
\text { stem }\end{array}$ & $\begin{array}{l}\text { one cup Boiled extract of } \\
\text { leaf and stem given } \\
\text { before tea. }\end{array}$ \\
\hline 30 & $\begin{array}{l}\text { Withania somanifera } \\
\text { (L.) Dunal }\end{array}$ & Solanaceae & Ashwgandha & $\begin{array}{l}\text { Root } \quad \& \\
\text { Leaves }\end{array}$ & $\begin{array}{l}\text { one cup Extract of root } \\
\text { and leaf given early in } \\
\text { the morning }\end{array}$ \\
\hline 31 & $\begin{array}{l}\text { Zingiber officinale } \\
\text { Rosc. }\end{array}$ & Zingiberaceae & Ginger & rhizome & $\begin{array}{l}\text { one teaspoon Extract of } \\
\text { rhizome is given early in } \\
\text { the morning }\end{array}$ \\
\hline 32 & $\begin{array}{l}\text { Ziziphus nummularia } \\
\text { (Burm.f.) Wight. }\end{array}$ & Rhamnaceae & Bor & Leaves, bark & $\begin{array}{l}\text { Extract and powder of } \\
\text { given before early in the } \\
\text { morning }\end{array}$ \\
\hline
\end{tabular}

